logos_i_ethos_2021_1_(56), s. 101-118

DOI: http://dx.doi.org/10.15633/lie.3941

Nina Putała

https://orcid.org/0000-0002-2084-2518

Uniwersytet Papieski Jana Pawła II w Krakowie

\title{
Problem ideałów w twórczości i życiu Fiodora Dostojewskiego. Polemika z uwagami Lwa Szestowa
}

\section{Kontekst}

Fiodor Dostojewski żył w latach 1821-1881. Jego aktywność literacka rozwijała się w okresie, gdy w Rosji nie było możliwości swobodnego wyrażania poglądów. Kraj był poddany dyktaturze cara, co wiązało się z odcięciem od Europy Zachodniej. Zwalczano wszelkie przejawy budo-

Nina Putała - doktorantka filozofii Uniwersytetu Papieskiego Jana Pawła II w Krakowie. Jej zainteresowania badawcze skupiają się wokół fenomenologii, aksjologii fenomenologicznej oraz filozofii medycyny. W tym zakresie opublikowała artykuł pt. Holistic model as a challenge for the medical profession (2020) oraz prowadziła badania Doświadczenie wartości w zawodzie lekarza (2018-2020). wania tradycji filozoficznej niezależnej od porządku monarchicznej Rosji. Cenzurowano dzieła, które mogłyby podważać autorytet ówczesnej władzy. Niemniej jednak w latach 1845-1849 istniały ruchy niezależne od narzucanego światopoglądu ${ }^{1}$.

Przykładem takiej odrębnej od władzy inicjatywy jest działalność rewolucyjnego ugrupowania określanego - od nazwiska jej głównego działacza Michaiła Butaszewicza-Pietraszewskiego - Kołem Pietraszewskiego. Była to jednocześnie dyskusyjna grupa literacka spotykająca się, aby analizować dzieła zachodnioeuropejskiej literatury i filozofii.

1 Por. J. Kroczak, Polskie badania filozofii Fiodora Dostojewskiego, „Slavia Orientalis” 2013 no. 3, s. 405 . 
Zainteresowanie myślą zachodnią stało się wyrazem sprzeciwu wobec despotyzmu cara i zbytniego odcięcia Rosji od innych krajów².

Władze, zaniepokojone działalnością koła, skazały jego członków na karę śmierci. Pośród nich był Dostojewski, który należał do ugrupowania. Świadomość końca życia znalazła odzwierciedlenie w twórczości pisarza, a w szczególności w podejmowanych przez niego wątkach religijnych. Ostatecznie, Dostojewski, stojąc przed plutonem egzekucyjnym, dowiedział się, że kara śmierci została zamieniona na zesłanie na Syberię ${ }^{3}$.

Pisarz należał do Koła Pietraszewskiego, ale wypracował własne poglądy, niezależne od stanowiska innych członków organizacji. Swoje inspiracje czerpał nie tylko z ruchów, które były nastawione okcydentalistycznie, lecz także z przeciwnej światopoglądowo opcji, jaką reprezentowali słowianofile, głoszący przekonania ludowe i nacjonalistyczne.

Interpretatorzy twórczości Dostojewskiego zauważają, że jego poglądy zbliżyły się do „paczwiennictwa” - idei „powrotu inteligencji do gleby" ${ }^{4}$, do tego, co narodowe. Pisarz wierzył w szczególne znaczenie rosyjskiego ludu. Cenił ludzi prostych, przywiązanych do tradycji i duchowości. Uważał, że ich postawa sprzyja ochronie podstawowych wartości ${ }^{5}$. Sam w Dzienniku pisarza nazywa siebie słowianofilem ${ }^{6}$. Przy tym nie odnosił się krytycznie do dokonań Europy Zachodniej. Starał się godzić przeciwne światopoglądy. Negatywnie oceniał jedynie odizolowanie inteligencji rosyjskiej od tradycji kraju i zbyt pochopne oderwanie nauki od wiary. Postulował, aby wraz ze wzrastającym zainteresowaniem tym, co obce, nie zatracano narodowego i religijnego dziedzictwa ${ }^{7}$.

2 Por. J. Kroczak, Polskie badania filozofii Fiodora Dostojewskiego, dz. cyt., s. 405.

3 Por. M. Kruszelnicki, Fiodor M. Dostojewski wobec problemu śmierci i nieśmiertelności, „Humanistyka i Przyrodoznawstwo” 21 (2015), s. 265.

4 Por. A. de Lazari, W kręgu Fiodora Dostojewskiego. Paczwiennictwo, Łódź 2000, s. 27-28.

5 Por. A. de Lazari, W kręgu Fiodora Dostojewskiego. Paczwiennictwo, dz. cyt., s. 27-28.

6 Por. F. Dostojewski, Dziennik pisarza, t. 3, przeł. M. Leśniewska, Warszawa 1982, s. 207-208.

7 Por. A. Kościółek, „Dziennik pisarza” Fiodora Dostojewskiego. Próba monografii, Toruń 2000. 


\section{Interpretacyjny klucz do twórczości Fiodora Dostojewskiego}

Niełatwo jednoznacznie określić, jakie są ostateczne rozstrzygnięcia egzystencjalnych problemów, które pisarz formułuje w swoich dziełach. Po pierwsze dlatego, że są one przedstawione za pośrednictwem literackich postaci, a po drugie, utrudnieniem jest sam charakter filozofii pisarza, otwartej na nowe pytania i sprzeczności. Dostojewski rozważa problem człowieka poprzez antynomiczne przedstawienie egzystencji. Pokazuje tkwiące $\mathrm{w}$ bohaterach dobro, aby następnie wykreowane postaci upodlić, przedstawiając je w najgorszych upadkach i uwikłaniach, do jakich zdolny jest człowiek. W takim rozpięciu ludzkiej natury człowiek w filozofii Dostojewskiego wydaje się - mówiąc za Blaise Pascalem - „pośrodkiem między niczym a wszystkim”. Żadna z pobudek ludzkiego życia - czy to moralnie pozytywna czy negatywna - nie stanowi rozstrzygnięcia na temat tego, kim człowiek jest. Czyny bohaterów nie są poddane przez samego autora jednoznacznej ocenie etycznej, dlatego interpretatorzy Dostojewskiego na próżno szukają ostatecznych poglądów pisarza.

Lew Szestow (1866-1938) - rosyjski filozof - krytykuje w ogóle próbę usystematyzowania poglądów Dostojewskiego. Sądzi, że nie tylko jest to niemożliwe, ale też naiwne. W tekstach pisarza można bowiem odnaleźć niejedno dno, więc łatwo dać się oszukać. Nie wiadomo, które poglądy są rzeczywiście tożsame z myślą Dostojewskiego, a które są tylko literacką kreacją. Szestow kpi z interpretacji, których kluczem są kategorie odnoszące się do wybranego ontologicznego bądź aksjologicznego porządku. W swojej książce Dostojewski i Nietzsche. Filozofia tragedii rezygnuje z próby przypisania poglądów Dostojewskiego do określonych nurtów, raczej prowadzi swobodną refleksję nad jego dziełami. Analizy przeprowadzone przez Szestowa nie zmierzają do odpowiedzi na pytanie o to, jak rzeczywiście Dostojewski charakteryzuje człowieka, lecz odsłaniają to, jakim on sam był człowiekiem. Szestow przywołuje z biografii pisarza sytuacje graniczne i stopniowo obnaża jego egzystencjalną

8 B. Pascal, Myśli, przeł. T. Żeleński (Boy), Warszawa 1983, s. 49. 
kondycję. Filozof wychodzi bowiem z założenia, że Dostojewski - w istocie - nie pisał swoich książek dla czytelników, ale opisując losy bohaterów, sam stawiał dramatyczne pytania o własne życie.

Szestow nie bez powodu nazywa Dostojewskiego „filozofem tragedii”. Śledzi rozwój myśli rosyjskiego pisarza i stawia tezę, że Dostojewski, doświadczając nieznośnej realności codziennych zmagań - podobnie jak bohaterowie jego książek - utracił wiarę w ideały i stał się człowiekiem z podziemia. Opinia Szestowa jest śmiała, więc trudno przyjąć ją bez momentu zawahania. Nie można natomiast odmówić rosyjskiemu filozofowi dociekliwości w stawianiu pytań, a to sprawia, że Dostojewski poprzez tekst Szestowa „odżywa” - jakby sam był postacią pisaną piórem Szestowa i podejmował z nim filozoficzny dialog. Jednocześnie trudno na podstawie tego rodzaju rozważań rozstrzygać, jaka jest prawda o samym Dostojewskim. Nie należy o tym zapominać, że Dostojewski z książki Szestowa staje się figurą (środkiem), która służy filozofowi do ukazania własnych poglądów.

Autor Filozofii tragedii - w znamiennym dla siebie stylu - narzuca swoją interpretację dzieł Dostojewskiego, ale nie jest to - wbrew pozorom - sposób na uniknięcie ewentualnej polemiki. Przeciwnie, poprzez prowokacyjny styl zaprasza czytelników do dyskusji. Wypada więc zapytać - czy Szestow miał rację, pisząc o Dostojewskim, że stał się człowiekiem podziemia. Czy rzeczywiście trudne realia życia zmiażdżyły ideały rosyjskiego pisarza? I w końcu, kim - rzeczywiście - był Dostojewski i czym charakteryzuje się jego pogląd na człowieka?

\section{Filozoficzny obraz pisarza według Lwa Szestowa}

Analizując dzieła Dostojewskiego, nie sposób pominąć tematu cierpienia, niejednokrotnie podnoszonego przez pisarza. Charakterystyczną cechą wielu spośród wykreowanych przez niego postaci jest pokora w znoszeniu trudów życia. Pisarz z dużym uznaniem odnosił się do postawy samowyrzeczenia, która jest związana z doświadczeniem cierpienia. Sam przyznał, że kwestia ta jest dla niego wyjątkowa. Dzielił się z czytelnikami, że największym szczęściem nie są dla niego sukcesy. Nie 
dawały mu satysfakcji ani pochwały znawców literatury, ani też wydanie dobrej powieści. Szczęściem - co może zaskakiwać - określa moment wzruszenia nad niesprawiedliwością losu Makarego Diewuszkina, bohatera Biednych ludzi.

Szestow analizuje wypowiedzi pisarza, wskazując na jego nieuzasadnioną egzaltację w opisywaniu cierpienia. Nie wierzy Dostojewskiemu. Nie sądzi, aby to akt współodczuwania z zapomnianymi prostaczkami skłaniał pisarza do uwznioślenia ich niedoli. Filozof próbuje udowodnić, że nie jest to autentyczny podziw, lecz wynik resentymentu. Wystarczy zdaniem Szestowa - przyjrzeć się postaci poczciwego księcia Myszkina z powieści Idiota. W mniemaniu Szestowa postać ta jest „płaska” i nie ma w niej naturalności, która byłaby oznaką pokrywania się poglądów pisarza i bohatera. Jest to postać wymyślona "na siłę" i po to, aby Dostojewski mógł się łudzić, że nadal istnieje jakiś aksjologiczny porządek, który uzasadnia trud i cierpienie ponoszone w imię wartości.

Filozof zauważa, że Dostojewski, wskazując na różnego rodzaju ideały, myśli życzeniowo. W jego opinii wypowiedzi z Dziennika pisarza są wyrazem histerii, a nie autentycznej wiary w możliwość istnienia dobra w ludziach. Forma literacka i nadmierny patos - jego zdaniem stanowią jednak złudny sposób na podtrzymanie młodzieńczej wiary w ideały. Romantyzm pisarza wobec realiów stopniowo ustępuje. Idąc za tropem rozważań Szestowa, można już tylko prześmiewczo zawtórować, że Dostojewski popadłszy w melancholię, wywoływał duchy, które nie istnieją. Resentyment Dostojewskiego miałby powstać na bazie doświadczeń pisarza. Według Szestowa Dostojewski sam czuł się odrzucony przez swojego mistrza, krytyka literackiego - Wissariona Bielińskego i stąd z niezwykłą czułością traktował bohaterów wyśmiewanych przez otoczenie. Filozof pokazuje, że pokorne przyjmowanie cierpień, na jakie stać fikcyjnych bohaterów z książek, nie jest możliwe dla zwykłego człowieka i Dostojewski wobec przeciwności losu w końcu zdał sobie $\mathrm{z}$ tego sprawę.

W życiu Dostojewskiego nastąpił moment załamania. Pisarz przestał cieszyć się na wieść o dobrych zmianach w Rosji. Czytając Filozofię tragedii, wydaje się, jakby Dostojewski zbyt długo zwlekał z przyznaniem się 
do własnej naiwności. Szestow w następujących słowach zdradza „prawdę” o pisarzu: „On sam odrzucał od siebie myśl, że "podziemie», które tak plastycznie odmalował, nie jest mu całkiem obce, lecz jego własne i w rzeczywistości bardzo bliskie. Bał się upiornych obrazów, które stawały przed nim jak żywe, i wytężał wszystkie siły swojej duszy, aby je odpędzić od siebie, ukryć pod pierwszą lepszą myślą"9.

Powoli ustępuje upór Dostojewskiego. Ważna dla niego idea samowyrzeczenia wybrzmiewa jeszcze w Skrzywdzonych i poniżonych, ale w Notatkach $z$ podziemia Szestow nie odnajduje górnolotnych marzeń. Zachwyt nad „marnym człowiekiem” coraz częściej zostaje zastąpiony przez powątpiewanie i cynizm.

Filozof nie drwi jednak z Dostojewskiego po to, aby wyeksponować słabość jego charakteru, ale dlatego, aby go szczególnie docenić na tle innych myślicieli, a głównie idealistów. Dla Szestowa Dostojewski doświadczający kłamstwa wyznawanych idei godny jest uwagi. To on - zdaniem Szestowa - obok Fryderyka Nietzschego i Sørena Kierkegaarda dojrzewa do głębi poznania prawdy, która może się odsłonić tylko z samego ciężaru życia. Bo nie ma takiej prawdy, która byłaby dana a priori, jakby chciał młody Dostojewski. „(...) To nie człowiek goni za prawdą, jak sądził Schopenhauer, ale prawda za człowiekiem"10 - przypomina Szestow.

Jak mogłaby zatem wyglądać ostateczna konstatacja na temat twórczości Dostojewskiego, gdy podąży się kluczem interpretacyjnym zaproponowanym przez Szestowa? Przede wszystkim mówiąc o „człowieku” Dostojewskiego, należałoby mieć na uwadze doświadczenie upadku ideałów. Realność takich momentów najpełniej ujawnia to, kim człowiek jest. Dostojewski - z książki Szestowa - stał się filozofem dopiero wtedy, gdy nie był już w stanie uciekać przed ciężarem życia, porzucił potrzebę nadawania sensu ludzkim trudom i cierpieniu, a zaczął przyglądać się ludzkim słabościom. s. 47.

9 L. Szestow, Dostojewski i Nietzsche. Filozofia tragedii, przeł. C. Wodziński, Warszawa 1987,

10 L. Szestow, Dostojewski i Nietzsche. Filozofia tragedii, dz. cyt., s. 245. 


\section{Polemika z Lwem Szestowem - możliwe stanowisko Fiodora Dostojewskiego}

Szestow zarzuca Dostojewskiemu, że jego wczesne dzieła są wynikiem resentymentu. Czy filozof ma rację, podkreślając, że za afirmacją ofiarności, jaką wyraża Dostojewski, kryje się wstyd porażki? Rzeczywiście, można dopatrywać się dziwnej niezbieżności w wypowiedziach Dostojewskiego, która może sygnalizować brak przekonania co do głoszonych tez. Jest to widoczne, gdy zestawi się jego patetyczne, pełne nadziei wypowiedzi z Dziennika pisarza z opisem postaci jego książek - nierzadko przepełnionych goryczą, zwątpieniem i nienawiścią. Sądząc po samych tylko obiecujących sformułowaniach, np. dotyczących wizji Nowej Rosji, można by stwierdzić, że Dostojewski jest pełen optymizmu. Sam pisarz stwierdza o sobie w Dzienniku..., że jest marzycielem i słowianofilem. Miał pomysł na ochronę moralności narodu i widział też sposób włączenia myśli zachodniej do kultury rosyjskiej przy jednoczesnym zachowaniu tradycyjnych wartości. I w końcu Dostojewski mocno wierzył w Chrystusa i dobro, które wiąże się z zawierzeniem Rosji Bożej opiece.

Świat taki jednak nie był i Dostojewski - pomimo marzeń - musiał doskonale zdawać sobie z tego sprawę. Pisarz nie tylko dostrzegał, że ludzie ulegają złu, które czyni z nich marionetki nieświadome swoich czynów, ale też sam doświadczał zła, bólu i nietolerancji. To przez ludzi cierpiał na zesłaniu. Adolf Rudnicki dzieli się następującą refleksją o Dostojewskim: „Jeśli nawet przyjąć, że to człowiek wierzący, nie ma w jego wierze, i wie on o tym, zabezpieczeń ani przed podłością, ani przed okrucieństwem"11. Należy jednak zauważyć, że doświadczenie zła nie musi od razu doprowadzać do negacji sensu odnoszenia się do ideałów, a samo skierowanie ku nim nie jest z konieczności naiwną wiarą - jakby chciał Szestow. Czy miałoby się spełnić życzenie autora Filozofii tragedii tylko dlatego, że Dostojewski zobaczył oczami zmęczonego człowieka, że świat jest okrutny? Upadek nadziei nie musi przecież oznaczać jej negacji w ogóle.

11 A. Rudnicki, Sto lat temu umarł Dostojewski, Kraków 1989, s. 131. 
Można zgodzić się z Szestowem, że Dostojewski weryfikował ideały, zmęczył siężyciem, a w jego wypowiedziach można odnaleźć sprzeczności, ale jednocześnie wątpliwe jest zdanie Szestowa, jakoby Dostojewski odrzucił sens samego ukierunkowania na idee, np. ważną dla niego ideę samowyrzeczenia. Doświadczenie rozczarowania quasi-prawdą, quasi-dobrem czy powszechnym porządkiem wydaje się należeć do obu myślicieli, ale ich stosunek do samego doświadczenia rozczarowania jest odmienny. To dla filozofii Szestowa znamienna jest negacja apriorycznego, racjonalnego założenia o istnieniu transcendentaliów oraz krytyka ofiarności dokonanej na tej podstawie. Nie ma jednak niepodważalnych przesłanek, które pozwalałyby na przypisanie takiego stanowiska również Dostojewskiemu.

Wypada więc wyjaśnić, jaka jest propozycja filozoficzna samego Dostojewskiego. Aby to pokazać, wrócę do omawianego wcześniej przykładu wzruszenia się Dostojewskiego postacią Makarego Diewuszkina. Szestow nie wierzy, że łzy wzruszenia nad Makarym Diewuszkinem są prawdziwe. Krytykuje ufność Dostojewskiego w ideę samowyrzeczenia. Tymczasem wzruszenie Dostojewskiego można wyjaśnić inaczej, nie zarzucając pisarzowi resentymentu.

Urzędnik Makary Diewuszkin jest poniżany przez innych, aczkolwiek w całym okrucieństwie zdarzeń, o jakich pisze Dostojewski, wciąż istnieje niewinność samej osoby - jakby oderwana $\mathrm{z}$ dynamiki wszelkich sytuacji bezwzględnego świata. I ten fenomen wewnętrznej moralności, tkwiącej w człowieku, wydaje się poruszać Dostojewskiego i wywoływać szczęście. Tu jest punkt rozłamu poglądów Szestowa i Dostojewskiego. Dostojewski, wbrew poglądom Szestowa, ufa w dobro, ku któremu człowiek stale się wychyla, choćby akt ten był naiwny jak u dziecka. Postaci z książek Dostojewskiego często zmagają się o taką wiarę. W utworze Sen śmiesznego człowieka czytamy: „O teraz żyć! Żyć całą duszą! Podniosłem w górę ramiona i wezwałem wieczną Prawdę. Nie, nie wezwałem, lecz zapłakałem; zachwyt, bezmierny zachwyt wypełniał całą moją istotę. (...) Nie chcę i nie mogę wierzyć, żeby zło było normalnym stanem ludzi"12.

12 F. Dostojewski, Sen śmiesznego człowieka, przeł. M. Leśniewska, w: F. Dostojewski, Opowieści fantastyczne, Kraków 2003, s. 157-158. 
Niestety - jak dowiadujemy się z dzieł pisarza - niewinność i pragnienie dobra poddawane są wypaczeniom. Zło ujawnia się na poziomie społecznych więzi. Relacje międzyludzkie i sytuacje tworzą skomplikowaną sieć zależności. Bohaterowie Dostojewskiego tkwią „w środku” zawiłych zdarzeń i dlatego trudno o dobre zakończenie opowieści o nich. Zwykle stają się i ofiarami, i oprawcami.

Dostojewski obserwował zarówno upadek człowieka, jak i ludzką wierność wobec ideałów, która nie zanika w wyniku egzystencjalnej próby. Nawet jeżeli pisarz stracił wiarę w możliwość istnienia dobrego świata (i w tym sensie Szestow ma rację), to jednocześnie autor Biednych ludzi nie poprzestaje na tym. Zadaje nowe pytanie - a mianowicie, zastanawia się, czy w złym świecie możliwy jest wybór dobra. W sytuacji, gdy świat jest zły, wybór moralny człowieka - zgodnie z fabułą dzieł Dostojewskiego - ostatecznie dotyczy dwóch opcji. Pierwszą z nich jest uległość wobec naporu zła i utrata ideałów. Wówczas skutkiem doświadczanego nieszczęścia jest gniew ukierunkowany na siebie bądź innych. Na przykład lichwiarz z opowiadania Potulna jest człowiekiem skrzywdzonym. Mści się na innych. Nie zauważa, że gniew, który w sobie nosi, ujawnia się w nieumiejętności nawiązania relacji z żoną i w coraz większym chłodzie wobec niej. W rezultacie postawa lichwiarza staje się dla Potulnej nie do wytrzymania i kobieta popełnia samobójstwo.

W filozofii Dostojewskiego demoralizacja bardzo często jest związana z poczuciem krzywdy, która pociąga do złych czynów. Najpierw dotyka ona człowieka, aby następnie stać się spiritus movens przemiany w sprawcę zła - dokonywanego na innych bądź zwróconego ku sobie samemu. W powieści Idiota książę Myszkin w następujący sposób analizuje wewnętrzną przemianę Nastazji Filipowny: „Ta nieszczęsna kobieta żyje w głębokim przekonaniu, że jest najbardziej upadłą, najbardziej zepsutą istotą na świecie. (...) I w czym ona jest winna, mój Boże! O, ona co chwilę woła, jak w szaleństwie, że nie uznaje swojej winy, że jest ofiarą ludzi, ofiarą rozpustnika i bezecnika, ale czego by nie mówiła, niech pani wie, że pierwsza samej sobie nie wierzy, a wierzy całym swoim sumieniem, że jest na odwrót, że... sama jest wszystkiemu winna. (...) Czy 
pani wie, że może w tej ciągłej świadomości własnej hańby zamyka się dla niej jakaś nienaturalna rozkosz, jakby to była zemsta na kimś"13.

Drugą opcją jest poniesienie ofiary, ale nie jest ona rodzajem agresji wobec siebie lub innych. Książę Myszkin wydaje się odporny na obelgi. Jest znieważany, ale nie przenosi tych reakcji na otoczenie. Jego postawa względem innych nie jest wynikiem uwikłania w przemoc, choć przemoc i nieszczęścia też go dotykają. Można by zapytać, co sprawia, że książę Myszkin nie ulega „skażeniu” złem? Czy istnieje jakaś ontologiczna zasada, która usprawiedliwiałaby trwanie w ideałach pomimo doświadczanych z tego powodu obelg? Dostojewski raczej nie daje odpowiedzi na takie pytania wprost, ale wydaje się, że dopuszcza możliwość istnienia zasady, która nadaje takiemu odniesieniu do ideałów sens. Co więcej - wydaje się, że sens odniesienia się do ideałów pozostaje utrzymany również wtedy, gdy pod wpływem egzystencjalnych doświadczeń samo wyobrażenie o ideałach ulega przekształceniu.

Niewątpliwie, jakąś podpowiedzią w tym zakresie jest religijna interpretacja odniesienia do ideałów, za którą Dostojewski wydaje się opowiadać. To nie człowiek ani życie uzasadniają sens podtrzymania ideałów, np. ideału dobra, lecz sens ten bezpośrednio wynika $\mathrm{z}$ istnienia Boga. On jest przyczyną ufności w nowy porządek aksjologiczny i podporą przekonania, że ideał dobra ma w Nim swoje urzeczywistnienie. Sprzeciw wobec zła - w filozofii Dostojewskiego - jest związany z relacją z Bogiem, która wprowadza inny porządek aksjologiczny niż jest nim hierarchia preferencji powstająca pod wpływem dynamiki życia. Na przykład, w postawie Makarego Diewuszkina można zaobserwować, że to nie zachowania innych osób i chęć zemsty stają się motywami działania, lecz zakładany aksjologiczny porządek, który skłania bohatera do wytrwałego spełniania obowiązków. Dostojewski uwznioślał wierność wobec Boga i trwanie w ukierunkowaniu na dobro - zwłaszcza wtedy, gdy chodziło o odniesienie do ideałów w niesprzyjających ku temu okolicznościach. 
Za pośrednictwem literackiego języka i wykreowanych postaci pisarz prowadził polemikę z filozofami, których myśl miała wpływ na światopogląd ówczesnego społeczeństwa. Był to dialog przede wszystkim ze zwolennikami filozofii Ludwiga Feuerbacha. Dostojewski krytykował Feuerbachowski antropoteizm, dopatrując się w odrzuceniu Boga istotnej przyczyny ludzkiego zagubienia ${ }^{14}$.

Czy wobec przeprowadzanych przez Dostojewskiego analiz zła można zarzucić pisarzowi naiwną wiarę w ideały? Wydaje się, że Dostojewski zarówno dostrzega realia demoralizacji, jak i zachowuje sens prostodusznego trwania w ideałach. Oceniając poglądy pisarza, warto zwrócić uwagę na rzecz następującą: Dostojewski poprzez swoje dzieła zaznajamia czytelników z różnymi profilami psychologicznymi, ukazując z jednej strony pozbawionych wrażliwości agresorów, $z$ drugiej, ofiary znoszące cierpienie i pragnące dobra. Szestow stwierdza, że właśnie te dobre postaci są przedstawione marionetkowo i nieprzekonująco, a to miałoby według Szestowa świadczyć o kondycji samego autora i jego sceptycyzmie.

Trudno zgodzić się z tą uwagą. O ile można dopatrywać się sztuczności pozytywnych postaci, o tyle trudno z tego powodu wyprowadzać wniosek o wątpliwościach Dostojewskiego. Sztuczność postaci może wynikać z chęci wyeksponowania określonego problemu. Dostojewski przejaskrawia wybrane cechy postaci (np. ufność, wierność, oddanie), ale w ten sposób wyraźniej odsłania, w jaki sposób pragnienie dobra zostaje zderzone z porządkiem sytuacyjnym.

Postać wydaje się być raczej odzwierciedleniem wybranej tendencji tkwiącej w człowieku, aniżeli reprezentacją realnej osobowości. Antagonizm bohaterów można odczytać nie tyle w odniesieniu do możliwego istnienia złych i dobrych ludzi - i co za tym idzie - jako naiwną wiarę autora w istnienie takich typów osobowych, ile jako zespół napięć, które dotyczą każdego człowieka. Za taką interpretacją przemawia fakt, że w szkicach do Idioty Myszkin i Ragożyn byli jedną postacią ${ }^{15}$. Ten

14 Por. M. Michalska-Suchanek, Samobójcy Fiodora Dostojewskiego, Katowice 2015, s. 26-28.

15 Por. M. Okłot, Czym on nas straszy?, https://www.tygodnikpowszechny.pl/czym-on-nas-straszy-143129 (12.01.2021). 
początkowy zamysł zespolenia dwóch przeciwnych charakterów w jednym bohaterze jeszcze wyraźniej pokazuje, że w twórczości rosyjskiego pisarza dialektyka przeciwnych skłonności ma istotne znaczenie.

Przy takiej interpretacji zarzut stawiany przez Szestowa o zbyt mało naturalnych postaciach wydaje się nietrafiony, gdyż w zamyśle samego autora postaci te nie reprezentacją realnych ludzi, lecz wskazują jedynie na skłonności do dobra i zła. Wobec tego trudno zarzucić Dostojewskiemu naiwną wiarę z powodu kreowania przez niego bohaterów marionetkowych i dobrodusznych. Na podstawie twórczości Dostojewskiego można jedynie przypuszczać, jakie jest przesłanie pisarza na temat egzystencji człowieka. Wydaje się, że według myśliciela dobre życie - w sensie życia szczęśliwego - nie jest możliwe w złym świecie, gdyż krzywda dotyka każdego. Możliwa jest jednak wiara, która jest wystarczająca do ocalenia wrażliwości na dobro, pomimo niesprzyjających ku temu okoliczności.

\section{Podsumowanie. Lew Szestow i Fiodor Dostojewski - różnica i podobieństwo}

Ostatecznie trudno dociec, jakie stanowisko przyjąłby Dostojewski wobec oskarżenia o resentyment. Nie należy zapominać, że rozważania nad filozofią rosyjskiego pisarza sprowadzają się do dyskusji nad możliwym poglądem kogoś, kto jest w roli twórcy fikcyjnych postaci. Niemniej jednak nie jest najważniejsze dotarcie do odpowiedzi na pytanie o to, kim Dostojewski był i czym charakteryzuje się jego osobisty pogląd na rzeczywistość. Wartością okazuje się również sama filozoficzna rozmowa, jaką Szestow wydaje się prowadzić z rosyjskim pisarzem. Zestawienie stanowiska Szestowa z postawą młodego Dostojewskiego (tak jak wykreował go Szestow) wyłania problematyczny wątek, który sam w sobie wart jest uwagi. Chodzi o możliwą postawę człowieka wobec dramatu tkwiącego w ludzkiej egzystencji.

Obraz człowieka targanego przez antagonistyczne siły dobra i zła wydaje się zbliżać obu myślicieli. Zarówno Dostojewski, jak i Szestow skupiają się nad opisem ludzkich prób wydostania się z trudnego położenia. 
Obaj myśliciele zauważają, że w każdym człowieku jest swego rodzaju „wychylenie” ku możliwemu dobru, oczekiwanie jakiegoś porządku. Wychylenie to jest jednocześnie sygnałem, że aktualna sytuacja egzystencjalna nie zaspokaja ludzkich potrzeb. Odsyła do czegoś spoza niej.

Z filozofii Szestowa dowiadujemy się, że reakcją na egzystencjalny niepokój jest szukanie oparcia w wytworach rozumu. Ale tego rodzaju ratunek - zdaniem filozofa - musi człowieka zawieść. Według niego nie istnieje prawda racjonalna, stała i jasna. Człowiek - w ujęciu jego filozofii - musi dojrzeć do gotowości uznania trudu egzystencji. Nie jest to jednak łatwe. Prawdziwy wgląd w realia egzystencji - jak przekonuje filozof - nie jest możliwy bez wiary w Boga. Człowiek wiary - wg Szestowa - jest gotowy zobaczyć i przyjąć życie takim, jakim jest - w całym jego chaosie, bo przyjmuje je, jako „przestrzeń” należącą do jego Stwórcy. Natomiast w przypadku braku wyboru Boga - jak zauważa Szestow ludzka postawa jest determinowana przez lęki i skłonności rozumu w zależności od okoliczności - czerpiącego z różnego rodzaju zniewoleń. Takim zniewoleniem może być filozofia, ideały, nauka, etyka czy przekonania. Bóg również - gdy jest wytworem rozumu - może być tą ucieczką. Stąd Bóg jako filozoficzne pojęcie nie ma nic wspólnego z Bogiem wiary. Według Szestowa wątpliwe jest, czy „Bóg filozofów” istnieje.

Odniesienie do prawdziwego Boga nie bierze się - jego zdaniem z potrzeby racjonalizacji tajemnic ludzkiego życia. Kto ufa w pojęcie absolutu, utworzone na drodze racjonalnego dochodzenia, ulega iluzji. Bogata treściowo rzeczywistość nie może być wyrażona w uporządkowanej terminologii. Potrzebna jest raczej autentyczna relacja, w której akty rozumu zostaną przekroczone na rzecz aktów wiary i oddania. Możliwość ta otwiera się wraz z gotowością zawieszenia spekulatywnych dociekań i poprzez demistyfikację wyznawanych idei, które niejako wciąż wyrastają w życiu człowieka na nowo. Szestow stwierdza, że również Dostojewski w wyniku autorefleksji doszedł do stanowiska krytycznego wobec ideałów, które hołubił w młodości. Pisze o nim: „Wyniósł z katorgi «przekonanie», że zadanie człowieka nie na tym polega, aby opłakiwać los Makarego Diewuszkina i marzyć o przyszłości, kiedy nikt już nikim nie będzie pogardzał i wszędzie będzie panował pokój, radość 
i szczęście, ale na tym, aby umieć przyjąć rzeczywistość ze wszystkimi jej potwornościami" ${ }^{\prime 16}$.

Powyższy fragment zdradza, że newralgicznym punktem rozważań Szestowa nad wyimaginowanym „psyche” Dostojewskiego jest problem nadziei w istnienie ontologicznego porządku. Szestow z czujnością wypatruje w życiu Dostojewskiego momentu, w którym upada nadzieja młodego pisarza na lepsze życie. Bo nadzieja tego rodzaju - zdaniem filozofa - musi upaść, aby mogła ukazać się egzystencja z całą swoją irracjonalną i bezwzględną siłą. Szestow wchodzi w rolę oskarżyciela. Podważa sens nadziei, którą Dostojewski zachowuje jeszcze u początków swojej pisarskiej kariery. Oszustwem jest dla niego wyczekiwanie prawdy, która nie wyłania się z samej dynamiki życia - wyczekiwanie oparte na racjonalnym rachowaniu, pozbawionym gotowości wyboru i uczestnictwa w tym, co dane człowiekowi aktualnie.

Zderzenie aktów rozumu i doświadczenia egzystencjalnego skłania filozofa do negacji wszystkiego, co nie może być odczuwane jako autentyczne bycie. Jednocześnie trudno odpowiedzieć na pytanie, czym miałaby być autentyczna postawa i czy jest ona możliwa. Sam Szestow zauważa, że człowiek nigdy nie uwolni się ze skłonności do racjonalizacji tego, co w istocie powinno pozostać tajemnicą i chaosem. Wydaje się, jakby autentyczna postawa nie była możliwa nigdy, bo zawsze jest skażona - mówiąc językiem Szestowa - grzechem racjonalizacji.

Jego wezwanie do weryfikacji ideałów nie jest jednakże pozbawione sensu. Proces upadku wyimaginowanego porządku - w filozofii Szestowa - jest dramatyczny, ale pozytywny, bo przygotowuje grunt do właściwej refleksji. Odważną argumentację filozofa można potraktować jako lekcję czujności i zachętę do autonomicznego myślenia. Szestow przede wszystkim nakłania do krytycznego podejścia do rozważań idealistów. Jego przenikliwość prowadzi do interesującego pytania o prawdziwość nadziei bądź jej fałsz. Jak przekonuje - nadzieja w istnienie aksjologicznego ładu może być wynikiem lęku. Taka nadzieja wzmaga wysiłki rozumu w kierunku tworzenia myślowych konstruktów, które jednak

16 L. Szestow, Dostojewski i Nietzsche. Filozofia tragedii, dz. cyt., s. 245. 
mogą okazać się niczym innym, jak ucieczką od trudu egzystencji i od pytań, na które nie ma łatwych odpowiedzi. Przy tym Szestow udowadnia, że wiara w Boga miałaby uzdalniać do przyjęcia życia, takim jakie ono jest, i odrzucenia wszelkich ideałów czy konstruktów myślowych, które są wynikiem lęku przed prawdziwym życiem.

Ale filozof posuwa się jeszcze dalej - krytykuje w ogóle możliwość apriorycznego poznania prawdy i dobra. W świetle takiego stanowiska nie dziwi fakt, że Szestow stara się podważyć możliwość istnienia poczciwego człowieka, podobnego do tytułowego Idioty z powieści Dostojewskiego. W filozofii Szestowa prawda nie może zostać odkryta za darmo. Próbuje on udowodnić, że prawda jest tylko na końcu drogi, jaką jest trudne doświadczenie, oraz dana jest tylko tym, którzy pomimo przeszkód odważyli się wyzbyć wszelkiego oparcia w ideałach. W tym punkcie filozofia tych dwóch rosyjskich myślicieli - Szestowa i Dostojewskiego - wydaje się rozchodzić.

Dostojewski - podobnie jak Szestow - postawił akcent na relację z Bogiem, ale przy tym nie przeprowadził rozrachunku ze skłonnościami rozumu. Pisarz starał się przede wszystkim pokazać, że wiara domaga się wyjścia poza spekulatywne dociekania i dokonanie konkretnego wybo$\mathrm{ru}$ - opowiedzenie się za Bogiem ${ }^{17}$. Nie wydaje się jednak, aby wybór wiary, do jakiego skłania, był związany z negacją metafizycznego porządku. Myśl Dostojewskiego odcina się od sceptycyzmu znamiennego dla Szestowa. Człowiek Dostojewskiego od początku wierzy - wychylony jest ku jakimś ideałom - również ideałom powstałym w wyniku chęci doświadczenia sensu przeżywanych trudów i niesprawiedliwego losu. Jeśli nawet pisarz przyznaje, że brak mu takiej wytrwałości, choć wzywa do tego, to owo wyznanie nie jest równoznaczne $\mathrm{z}$ dewaluacją samego aktu afirmacji ludzi gotowych do samowyrzeczenia w imię zakładanego w istnieniu aksjologicznego bądź ontologicznego porządku. Negatywne skłonności ludzkie oraz upadek kolejnych autorytetów nie umniejszają

7 Por. T. Obolevitch, Dostojewski jako metafizyk. Próba metarefleksji, w: Metafizyka a literatura w kulturze rosyjskiej. Метабизика и литература в русской культуре, red. T. Obolevitch, Kraków 2012, s. 175. 
ani wartości odniesienia do ideałów, ani wartości oczekiwania na dobro. Dostojewski, jeśli wyrzeka się ideałów młodości, to nie wyrzeka się jednocześnie sensu wiary w ideały.

Szestow wnikliwie analizuje skłonności człowieka do oszukiwania siebie, ale jednocześnie wydaje się zbyt jednostronnie określać funkcję, jaką spełniają ideały. Zakłada, że zawsze zamykają one horyzont możliwości bycia, kierunkując egzystencję wyłącznie na wyimaginowany porządek. Nadzieja istnienia czegoś lepszego nie musi jednak być z konieczności ucieczką od realności, gdy celem nie jest sama wyobrażona idea, lecz - jak pokazuje Dostojewski - obecność Chrystusa. Nadzieja, czy stojąca za nią idea, jest wówczas wyłącznie narzędziem - wołaniem otwierającym jakąś nową możliwość bądź to uzyskania treści adekwatnej do wyobrażenia, do którego nadzieja bezpośrednio się odnosi, bądź to doświadczenia niespodziewanej prawdy, która odsłania się właśnie dlatego, że nadzieja na coś lepszego usposabia do gotowości zadawania nowych pytań. Wówczas każda idea (niebędąca celem dla siebie samej) byłaby otwarciem i szansą przekraczania własnego porządku na rzecz relacji z Bogiem - czyli stanowiłaby zachętę do tego samego, co jest właśnie wezwaniem filozofii Szestowa.

\section{Bibliografia}

\section{Dzieła źródłowe}

Dostojewski F., Aforyzmy, przeł. Z. Podgórzec, R. Przybylski, Warszawa 1976.

Dostojewski F., Biedni ludzie, przeł. A. Stawar, w: F. Dostojewski, Białe noce i inne utwory, Warszawa 1992, s. 5-120.

Dostojewski F., Dziennik pisarza, t. 1-3, przeł. M. Leśniewska, Warszawa 1982.

Dostojewski F., Idiota, przeł. J. Gładyś, Kraków 2006.

Dostojewski F., Potulna, przeł. M. Leśniewska, w: F. Dostojewski, Opowieści fantastyczne, Kraków 2003, s. 720-130.

Dostojewski F., Sen śmiesznego człowieka, przeł. M. Leśniewska, w: F. Dostojewski, Opowieści fantastyczne, Kraków 2003, s. 131-159.

Dostojewski F., Skrzywdzeni i poniżeni, przeł. W Broniewski, Warszawa 1992.

Szestow L., Ateny i Jerozolima, przeł. C. Wodziński, Kraków 1993. 
Szestow L., Dostojewski i Nietzsche. Filozofia tragedii, przeł. C. Wodziński, Warszawa 1987. Szestow L., Na szalach Hioba. Duchowe wędrówki, przeł. J. Chmielewski, Warszawa 2003. Szestow L., Sole fide. Tylko przez wiarę, przeł. C. Wodziński, Warszawa 1995.

Literatura pomocnicza

Kościółek A., „Dziennik pisarza” Fiodora Dostojewskiego. Próba monografii, Toruń 2000. Kroczak J., Polskie badania filozofii Fiodora Dostojewskiego, „Slavia Orientalis” 2013 no. 3, s. 405-420.

Kruszelnicki M., Fiodor M. Dostojewski wobec problemu śmierci i nieśmiertelności, „Humanistyka i Przyrodoznawstwo” 21 (2015), s. 263-284.

de Lazari A., W kręgu Fiodora Dostojewskiego „Paczwiennictwo”, Łódź 2000.

Michalska-Suchanek M., Samobójcy Fiodora Dostojewskiego, Katowice 2015.

Obolevitch T., Dostojewski jako metafizyk. Próba metarefleksji, w: Metafizyka a literatura w kulturze rosyjskiej. Метафизика и литература в русской культуре, red. T. Obolevitch, Kraków 2012, s. 167-182.

Okłot M., Czym on nas straszy, https://www.tygodnikpowszechny.pl/czym-on-nas-straszy-143129 (12.01.2021).

Pascal B., Myśli, przeł. T. Żeleński (Boy), Warszawa 1983.

Rudnicki A., Sto lat temu umarł Dostojewski, Kraków 1989.

\section{Abstrakt \\ Problem ideałów w twórczości i życiu Fiodora Dostojewskiego. Polemika z uwagami Lwa Szestowa}

Lew Szestow w swoim studium nad twórczością i życiem Fiodora Dostojewskiego ukazuje pisarza jako myśliciela, który wraz z doświadczeniem życiowym wyzbywa się naiwnego odniesienia do ideałów i stopniowo odkrywa istotę dramatu ludzkiej egzystencji. Szestow - krytyk idealizmu i tradycji opartej na rozumie - pokazuje proces porzucania przez Dostojewskiego ideałów jako akt filozoficznej odwagi i wyjście z ograniczeń racjonalnego dyskursu. Przy tym Szestow pomija pozytywną, poznawczą funkcję odniesienia do ideałów, którą - zdaniem autorki - Dostojewski, wbrew przypisywanym mu przez Szestowa poglądom, zauważa. 


\title{
Słowa kluczowe
}

Lew Szestow, Fiodor Dostojewski, ideały, racjonalizm, egzystencja

\begin{abstract}
The problem of ideals in the works and life of Fyodor Dostoyevsky Polemic with Lev Shestov's remarks

In Shestov's study of the work and life of Fyodor Dostoyevsky, Shestov presents the writer as a thinker who, together with his life experience, disposes of naive reference to ideals and gradually discovers the essence of the drama of human existence. Shestov, a critic of idealism and reason-based tradition, shows Dostoyevsky's process of abandoning ideals as an act of philosophical courage and a way out of the limitations of rational discourse. At the same time, Shestov ignores the positive and cognitive function of reference to ideals, whereas Dostoyevsky distinguishes it despite the views attributed to him by Shestov, as the author observes.
\end{abstract}

\section{Keywords}

Lev Shestov, Fyodor Dostoyevsky, ideals, rationalism, existence 